\title{
African heritage sites threatened as sea-level rise accelerates
}

\author{
Michalis I. Vousdoukas $\mathbb{1}^{1 凶}$, Joanne Clarke $\mathbb{D}^{2}{ }^{2}$, Roshanka Ranasinghe $\mathbb{D}^{3,4,5}$, Lena Reimann ${ }^{6}$, \\ Nadia Khalaf $\mathbb{D}^{7}$, Trang Minh Duong $\mathbb{B}^{3,4,5}$, Birgitt Ouweneel ${ }^{8}{ }^{8}$, Salma Sabour ${ }^{10}{ }^{9}$, Carley E. Iles ${ }^{10}{ }^{10,11}$, \\ Christopher H. Trisos $\mathbb{D}^{8,12}$, Luc Feyen ${ }^{13}$, Lorenzo Mentaschi ${ }^{14}$ and Nicholas P. Simpson $\mathbb{D}^{8} \bowtie$
}

\begin{abstract}
The African coast contains heritage sites of 'Outstanding Universal Value' that face increasing risk from anthropogenic climate change. Here, we generated a database of 213 natural and 71 cultural African heritage sites to assess exposure to coastal flooding and erosion under moderate (RCP 4.5) and high (RCP 8.5) greenhouse gas emission scenarios. Currently, 56 sites $(20 \%)$ are at risk from a 1-in-100-year coastal extreme event, including the iconic ruins of Tipasa (Algeria) and the North Sinai Archaeological Sites Zone (Egypt). By 2050, the number of exposed sites is projected to more than triple, reaching almost 200 sites under high emissions. Emissions mitigation from RCP 8.5 to RCP 4.5 reduces the number of very highly exposed sites by $\mathbf{2 5 \%}$. These findings highlight the urgent need for increased climate change adaptation for heritage sites in Africa, including governance and management approaches, site-specific vulnerability assessments, exposure monitoring, and protection strategies.
\end{abstract}

H eritage sites have important cultural, ecological, historical, social and economic value ${ }^{1,2}$. Yet climate change hazards such as river floods, heatwaves and wildfires threaten heritage globally ${ }^{3-5}$. Multiple heritage sites, including World Heritage Sites of 'Outstanding Universal Value', are located in the low-lying coastal zone and therefore also face threats from coastal hazards due to rising sea levels. Sea levels have been rising at a faster rate over the past three decades compared with the twentieth century ${ }^{6,7}$, a process that is expected to gather pace through the twenty-first century ${ }^{8,9}$. Together with changing weather patterns $s^{10,11}$, this is expected to intensify coastal flooding ${ }^{12,13}$ and coastal erosion ${ }^{14}$, exacerbating damages to coastal zone assets ${ }^{15}$. However, in contrast to other continents ${ }^{16}$, few studies have assessed climate change risks along the $300,000 \mathrm{~km}$ African coastline that spans 39 countries $^{3,4,17}$. Even sparser is information about the future of the continent's cultural and natural heritage sites, many of which are found in the coastal zone.

We assess exposure of African heritage sites (AHS) to coastal flooding and erosion along the entire African coastline. We create the first continent-wide, digitized, geospatial database of 284 coastal AHS, combining 71 cultural World Heritage Sites and 213 natural World Heritage Sites that are either already recognized, or currently under consideration by the United Nations Educational, Scientific and Cultural Organization (UNESCO) World Heritage Centre and the Ramsar Convention on Wetlands of International Importance ${ }^{18-21}$. Our analysis focuses on the coastal area exposed to a 1-in-100-year (that is, once in a century) coastal flooding and coastal erosion event. We estimate the exposed area at each site for the baseline (reference year 2010), as well as through the twenty-first century, under moderate (Representative Concentration Pathway (RCP) 4.5) and high (RCP 8.5) greenhouse gas emission scenarios. To assess exposure to current and future coastal floods, we derive inundation maps using a hydrodynamic model forced by extreme sea levels (ESLs; combination of sea level, waves, tides and storm surges $)^{22}$. To assess coastal erosion, we post-process recent shoreline change projections ${ }^{14}$, together with site-specific geological information that can limit shoreline retreat. At each site we derive exposed area for flooding and erosion separately and then calculate the total exposed area as the union of these two, so that reported values express the combined effect. We present median values of exposed area, as well as the very likely range; expressed as the 5th and 95th percentiles. We provide information for each AHS and present our findings at country, regional and continental levels (see Methods for more details on the different steps of the analysis, including a detailed discussion of any limitations in a dedicated section).

Fifty-six (20\%) of the 284 identified AHS are currently exposed to a 1-in-100-year coastal extreme event. Thirty-five of the 213 natural heritage sites (16\%) and 21 of the 71 cultural heritage sites (30\%) are exposed to a 100-year coastal extreme event (Table 1), corresponding to $1,719 \mathrm{~km}^{2}$ and $419 \mathrm{~km}^{2}$ of exposed natural and cultural heritage area, respectively. On average, each site has $4.5 \%$ of its area exposed. Fifty sites have $<50 \%$ of their area exposed, 3 sites have $>50 \%$ area exposed and 3 sites have $>75 \%$ of their area exposed (Fig. 1).

North Africa has the largest number of exposed sites (23 of a total of 109; Extended Data Fig. 1). West Africa has 18 sites exposed, Southern Africa has 7, while East Africa and Small Island Developing

'Joint Research Centre (JRC), European Commission, Seville, Spain. ${ }^{2}$ School of Art, Media and American Studies, University of East Anglia, Norwich, UK. ${ }^{3}$ Department of Coastal and Urban Risk \& Resilience, IHE Delft Institute for Water Education, Delft, The Netherlands. ${ }^{4}$ Water Engineering and Management, University of Twente, Enschede, The Netherlands. ${ }^{5}$ Harbour, Coastal and Offshore Engineering, Deltares, Delft, The Netherlands. ${ }^{6}$ Institute for Environmental Studies (IVM), Vrije Universiteit Amsterdam, Amsterdam, The Netherlands. ${ }^{7}$ Institute of Arab and Islamic Studies, University of Exeter, Exeter, UK. ${ }^{8}$ African Climate and Development Initiative, University of Cape Town, Cape Town, South Africa. ${ }^{9}$ Faculty of Engineering and Physical Sciences, University of Southampton, Southampton, UK. ${ }^{10} \mathrm{C}$ enter for International Climate Research, Oslo, Norway. "Laboratoire des Sciences du Climat et de I'Environnement, LSCE/IPSL, CEA-CNRS-UVSQ, Université Paris-Saclay, Gif-sur-Yvette, France. ${ }^{12}$ Centre for Statistics in Ecology, Environment and Conservation, University of Cape Town, Cape Town, South Africa. ${ }^{13}$ Joint Research Centre (JRC), European Commission, Ispra, Italy. ${ }^{14}$ Department of Physics and Astronomy 'Augusto

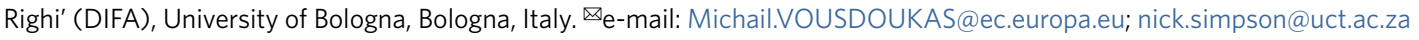


Table 1 | Coastal hazard exposure of cultural, natural and total AHS around the entire African coastline

\begin{tabular}{|c|c|c|c|c|c|c|}
\hline & & Baseline & RCP 4.5-2050 & RCP 4.5-2100 & RCP 8.5-2050 & RCP 8.5-2100 \\
\hline \multirow[t]{3}{*}{ Natural } & No. of sites & $35(35-35)$ & $151(151-152)$ & $151(150-152)$ & $154(154-160)$ & $154(152-160)$ \\
\hline & Area $\left(\mathrm{km}^{2}\right)$ & $1,300(1,298-1,303)$ & $1,313(1,308-3,105)$ & $\begin{array}{l}15,053 \\
(11,906-20,545)\end{array}$ & $1,645(1,321-3,297)$ & $\begin{array}{l}18,930 \\
(13,652-25,545)\end{array}$ \\
\hline & Average exposure (\%) & $5.1(5.0-5.1)$ & $5.2(5.1-5.9)$ & $12.4(10.4-15.7)$ & $6.1(5.1-6.5)$ & $15.0(11.6-20.4)$ \\
\hline \multirow[t]{3}{*}{ Cultural } & No. of sites & $21(21-21)$ & $40(40-44)$ & $40(40-44)$ & $44(44-50)$ & $44(40-50)$ \\
\hline & Area $\left(\mathrm{km}^{2}\right)$ & $419(417-421)$ & $431(420-576)$ & $1,585(1,287-2,051)$ & $527(436-635)$ & $2,039(1,516-2,507)$ \\
\hline & Average exposure (\%) & $2.7(2.6-2.8)$ & $2.8(2.7-3.6)$ & $7.8(6.5-9.7)$ & $3.3(2.7-4.0)$ & $9.7(7.7-12.0)$ \\
\hline \multirow[t]{3}{*}{ Total } & No. of sites & $56(56-56)$ & $191(191-196)$ & $191(190-196)$ & $198(198-210)$ & $198(192-210)$ \\
\hline & Area $\left(\mathrm{km}^{2}\right)$ & $1,719(1,715-1,721)$ & $1,744(1,728-3,681)$ & $\begin{array}{l}16,638 \\
(13,192-22,596)\end{array}$ & $2,171(1,757-3,932)$ & $\begin{array}{l}20,969 \\
(15,168-28,051)\end{array}$ \\
\hline & Average exposure (\%) & $4.5(4.4-4.6)$ & $4.6(4.5-5.4)$ & $11.2(9.4-14.2)$ & $5.4(4.5-5.9)$ & $13.7(10.7-18.3)$ \\
\hline
\end{tabular}

Area (in $\mathrm{km}^{2}$ ) and number of sites exposed to the 100-year coastal extreme event. In addition, the average percentage of the sites' exposure is shown (exposed area divided by the total site's area). The values correspond to the baseline (2010), as well as the different emission pathways RCP 4.5 and RCP 8.5, by 2050 and 2100 . Values in brackets indicate the very likely range (5th-95th percentiles).

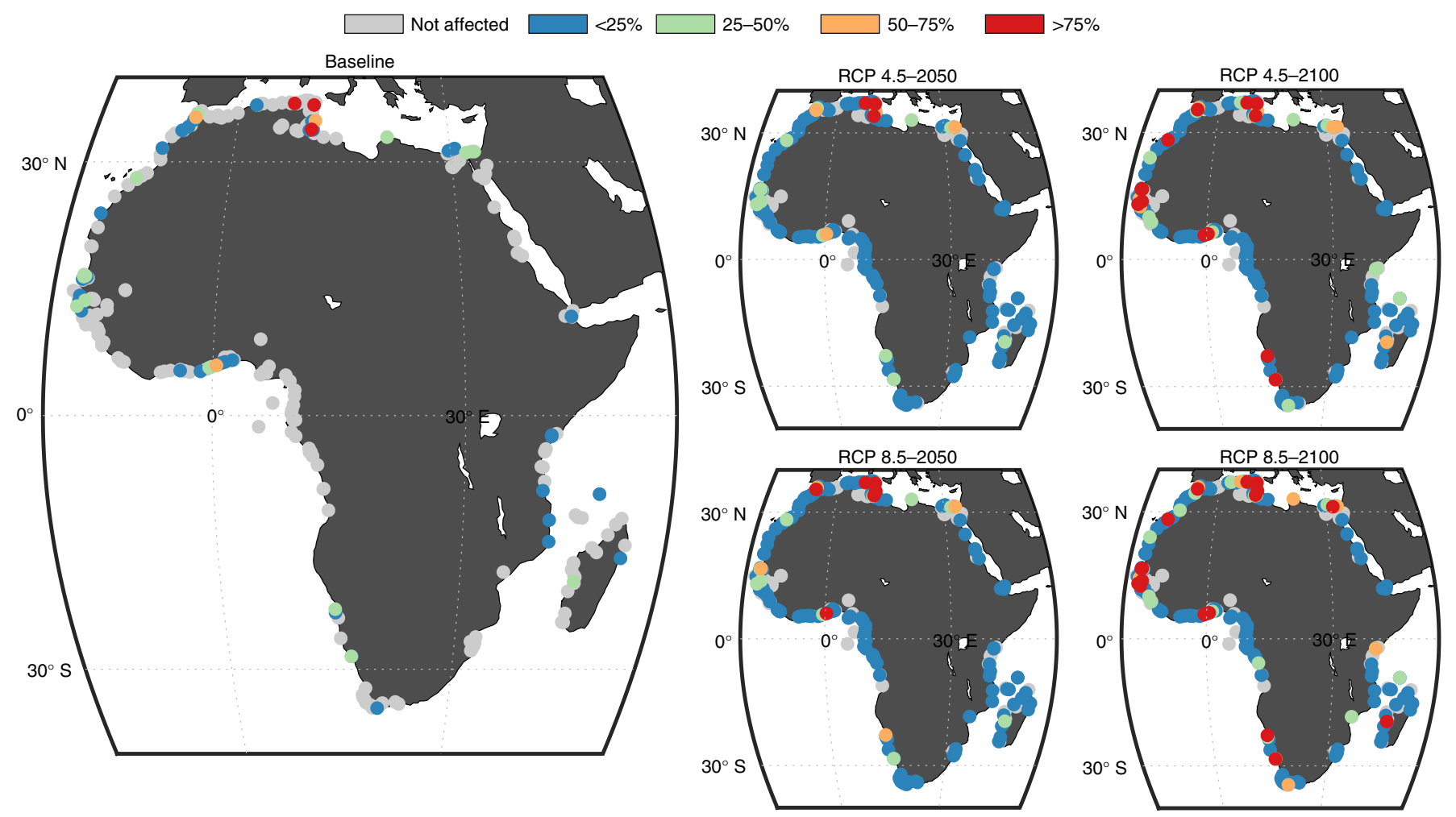

Fig. 1 Rising seas expose more AHS to coastal hazards by 2050. Maps of AHS affected by the 100-year coastal extreme event during the baseline period and under RCP 4.5 and RCP 8.5, for 2050 and 2100. The dots indicate the location of the sites. The colours blue, green, orange and red show that the fraction of the site's total area exposed to coastal hazards is $<25 \%, 25-50 \%, 50-75 \%$ or $>75 \%$, respectively.

States (SIDS) each have 4 exposed sites. Tunisia contains the most heritage sites (34), 7 of which are exposed to a 100-year event, with 2 of them being highly exposed ( $>75 \%$ exposed area). Morocco and Senegal have 7 exposed sites each and Egypt has 4 . No Central African sites are currently exposed.

The number of sites threatened by a 100 -year coastal extreme event is projected to more than triple under moderate emissions, reaching 191 (very likely range: 191-196) by 2050 (Table 1). Considering the median estimates, 68, 47, 24, 23, 16 and 13 exposed sites are found in North, West, Southern, SIDS, Central, and East Africa, respectively. High emissions will increase the total number of exposed sites by 2050 to 198 (very likely range: 198-210), with 4 of the 7 additional sites (for the median estimate) found in North Africa and 3 distributed among the SIDS, Southern and West Africa.

For both moderate and high emissions scenarios, the number of exposed sites remains stable in the second half of the century, but there is a sharp increase in the level of exposure. Under RCP 4.5, the number of very highly exposed sites (that is, fraction of site's exposed area $>75 \%$ ) increases fivefold from the present-day value, to reach 15 sites (14-20) by 2100 ; while under high emissions this estimate increases more than sixfold to 20 (17-30; Fig. 1). The latter is the result of the fact that the increase in exposed heritage area 

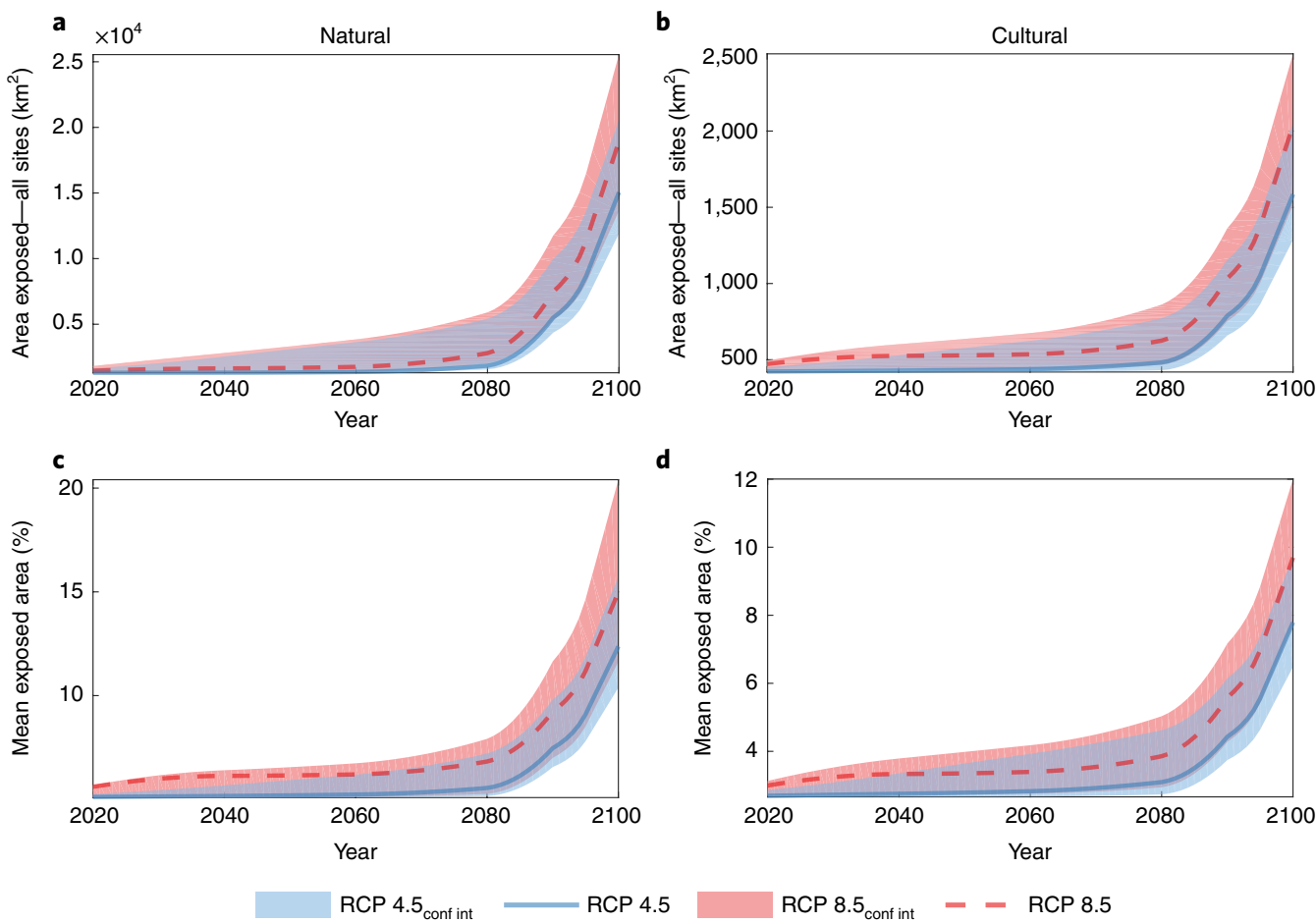

Fig. 2 Increasing exposure of AHS affected by the 100-year coastal extreme event, during the twenty-first century. a-d, Time evolution of the area (a,b) and mean fraction of area $(\mathbf{c}, \mathbf{d})$ of natural $(\mathbf{a}, \mathbf{c})$ and cultural $(\mathbf{b}, \mathbf{d})$ sites exposed to coastal floods and erosion. Median values are shown for RCP 4.5 (blue solid line) and RCP 8.5 (red dashed line), while respectively shaded areas indicate the very likely range (5th-95th percentiles; indicated as 'conf int' in the legend). The left vertical axis expresses the total exposed area in $\mathrm{km}^{2}$ for all sites $(\mathbf{a}, \mathbf{b})$ and the average of the percentage of each site's exposed area $(\mathbf{c}, \mathbf{d})$.

accelerates as sea-level rise gathers pace (Fig. 2). By 2050 and under high emissions, the median additional exposed area is limited to about $25 \%$ of the baseline value $\left(1,719 \mathrm{~km}^{2}\right.$ versus $\left.2,171 \mathrm{~km}^{2}\right)$, while under moderate emissions the increase is less than $2 \%$. However, by the end of the century the median additional exposed area increases by 9.5 times its present-day value under moderate emissions, reaching a total exposed area of $16,638 \mathrm{~km}^{2}(13,192-22,596$; Table 1$)$. The median exposed area under high emissions is $20,969 \mathrm{~km}^{2}(15,168-$ 28,051 ), about 12 times the baseline value (Table 1). These findings underline the benefits of reducing greenhouse gas emissions, as mitigation from high to moderate emissions would result in a $21 \%$ reduction of the median exposed area, as well as $25 \%$ fewer sites that would be highly exposed by the end of the century (Fig. 1).

On average, AHS will have 11.2\% (9.4-14.2) and 13.7\%(10.7-18.3) of their area exposed under moderate and high emissions, respectively (Table 1). These percentages are higher for natural sites than for cultural sites; for example, under high emissions, $15 \%$ (11.6-20.4) versus $9.7 \%$ (7.7-12.0), respectively, by the end of the century (Fig. $2 \mathrm{c}, \mathrm{d}$ ). Note that the mean exposed area is used as a proxy of the overall effect of coastal hazards on AHS, but it doesn't imply that sites are interchangeable, nor that the characteristics of each site are homogeneous. Each site contains unique outstanding value, can be made up of multiple components, and potential loss even across one site would probably be unequal. Projections show that at least 151 natural and 40 cultural sites will be exposed to the 100 -year event from 2050 onwards, regardless of the scenario (median values, Table 1). As natural sites occupy almost 10 times more area than cultural ones, most of the exposed area belongs also to the former. Under moderate emissions and by the end of the century, the exposed natural and cultural area will be equal to $15,053 \mathrm{~km}^{2}(11,906-20,545)$ and $1,585 \mathrm{~km}^{2}$ (1,287-2,051), respectively (Table 1 and Fig. 2a,b). Under high emissions, the same values rise to $18,930 \mathrm{~km}^{2}(13,652-25,545)$ and $2,039 \mathrm{~km}^{2}(1,516-2,507)$, respectively.
At country level and in terms of median estimates, there are several countries that are projected to have all their coastal heritage sites exposed to the 100-year coastal extreme event by the end of the century, regardless of the scenario: Cameroon, Republic of the Congo, Djibouti, Western Sahara, Libya, Mozambique, Mauritania and Namibia (Fig. 3 and Table 2). Under high emissions and for the worst-case scenario (that is, 95th percentile), four more countries are added to this list: Côte d'Ivoire, Cabo Verde, Sudan and Tanzania. Morocco and Tunisia have the highest number of sites exposed by 2100 , at least 13 more than at present (and at least 20, regardless of the scenario). With respect to the heritage area exposed, Mozambique is the most exposed country (median value exceeding 5,683 $\mathrm{km}^{2}$ under moderate mitigation; Fig. 3), followed by Senegal $\left(>2,291 \mathrm{~km}^{2}\right)$, Mauritania $\left(>1,764 \mathrm{~km}^{2}\right)$ and Kenya $\left(>822 \mathrm{~km}^{2}\right)$. Tanzania, Mozambique, Côte d'Ivoire, Benin, Togo and South Africa are countries that by the end of the century will have at least 100 times more exposed heritage area than at present. Ghana, Sierra Leone, Libya, Mozambique and Seychelles are projected to have $51 \%, 30 \%, 25 \%, 21 \%$ and $20 \%$ of their heritage area exposed by the end of the century, respectively, under high emissions (Fig. 4).

SIDS heritage sites are especially at risk. For example, Curral Velho $(1,575$, Ramsar site in Cabo Verde) is an important wetland that will be exposed to coastal hazards by 2050 . Under high emissions and by the end of the century, $44 \%$ of the site's total area will be exposed. Aldabra Atoll $(1,887)$, the world's second-largest coral atoll, and Kunta Kinteh Island (The Gambia) could both see up to $17 \%$ and $46 \%$ area exposed by 2100 under high emissions, respectively.

Notable increases of percentage site exposure are also projected for some archaeological and cultural sites, such as the North Sinai Archaeological Sites Zone (189; 91\%; RCP 8.5, 2100), Agglomération Aného-Glidji (1,505; 37\%; RCP 8.5, 2100), the ancient Punic and 


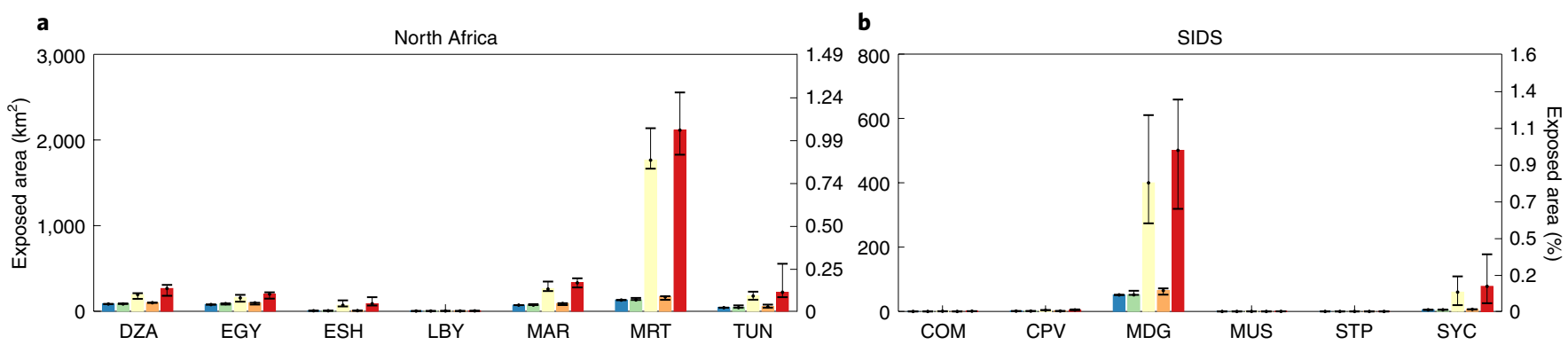

C Western Africa
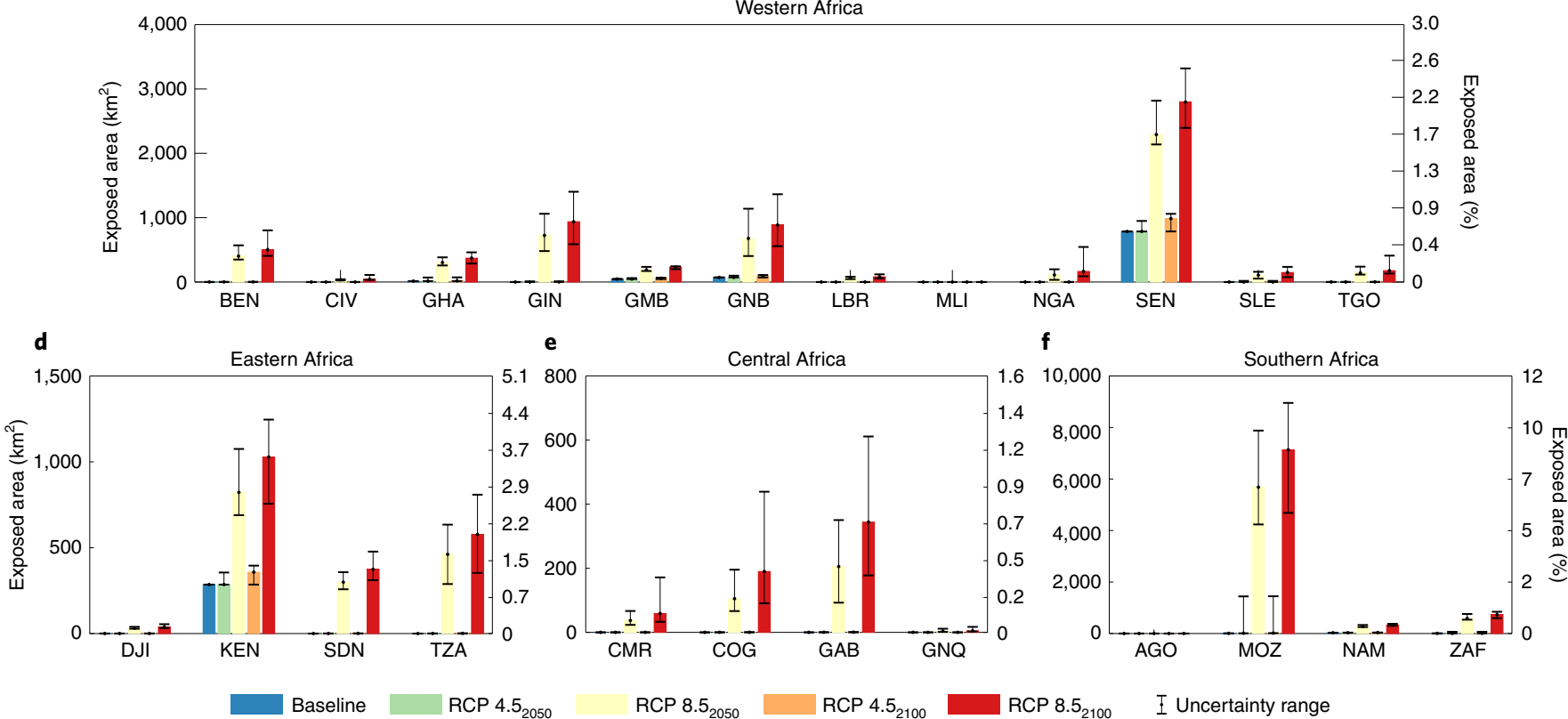

Fig. 3 Country estimates of the area of AHS affected by the 100-year coastal extreme event during the twenty-first century. a-f, Projections are grouped in regional subplots for North Africa (a), SIDS (b), Western Africa (c), Eastern Africa (d), Central Africa (e) and Southern Africa (f), with blue indicating the baseline (2010) and green, yellow, orange and red corresponding to projections for the different emission pathways RCP 4.5 (green, orange) and RCP 8.5 (yellow, red), by 2050 and 2100, respectively. Thin bars indicate the very likely range (5th-95th percentiles), and the left and right vertical axis expresses affected area in $\mathrm{km}^{2}$ and the corresponding percentage of the total sub-regional area, respectively. DZA, Algeria; AGO, Angola; BEN, Benin; CPV, Cabo Verde; CMR, Cameroon; COM, Comoros; COG, Congo; CIV, Côte d'Ivoire; DJI, Djibouti; EGY, Egypt; GNQ, Equatorial Guinea; GAB, Gabon; GMB, Gambia; GHA, Ghana; GIN, Guinea; GNB, Guinea-Bissau; KEN, Kenya; LBR, Liberia; MDG, Madagascar; MRT, Mauritania; MUS, Mauritius; MAR, Morocco; MOZ, Mozambique; NAM, Namibia; NGA, Nigeria; STP, Sao Tome and Principe; SEN, Senegal; SYC, Seychelles; SLE, Sierra Leone; ZAF, South Africa; LBY, State of Libya; SDN, Sudan; TGO, Togo; TUN, Tunisia; TZA, United Republic of Tanzania; ESH, Western Sahara (occupied territory).

Roman trading post, Tipasa (193; 11\%; RCP 8.5, 2100), the archaeological site, Sabratha $(184 ; 7.7 \%$; RCP $8.5,2100)$ and the archaeological site, Carthage (37; 5.9\%; RCP 8.5, 2100). Although Qaitbay Citadel, the ancient site of the Lighthouse of Alexandria $(1,822)$ and one of the Seven Wonders of the Ancient World ${ }^{23}$, is projected here to experience minimal exposure due to existing protections, it has already experienced severe flooding in 2019 , leading to the construction of coastal defences ${ }^{24}$.

Chat Tboul $(1,044)$ and Parc National du Diawling (666) in Mauritania are examples of sites already exposed to extreme flood events despite efforts to ecologically restore the floodplain ${ }^{25,26}$. Similarly, the vulnerability of the socio-ecological system of the Densu River Basin (Ghana) might be accentuated by the predicted total flooding of the Densu Delta Ramsar site (564) by 2100 under both emission scenarios, compared with a present-day value of only $47 \%$ area flooded ${ }^{27}$. Relict Guinean coastal forests have already largely disappeared due to coastal erosion ${ }^{28,29}$. For Parc National du Diawling (666), future flooding and erosion will affect the entire site, compared with a baseline of only $45 \%$ area exposed. Such a substantial increase may affect the ecological equilibrium of the site's ecosystem.
Africa is home to some of the most diverse cultural and bio-cultural heritage in the world, internationally recognized for its

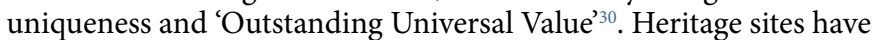
continuously served as 'living' heritage ${ }^{31}$ and therefore are deeply interwoven with the people's identity and tradition, are essential for social wellbeing, safeguarding traditional knowledge and livelihoods, and constituting a prerequisite for sustainable development $^{32}$. Yet, we find that 1 out of 5 coastal AHS are already at risk from a 1-in-100-year ESL event, a number that is projected to almost quadruple by the end of the century.

More heritage area is exposed to flooding compared with erosion, but as the impact mechanism of the two hazards is different, their relative importance is site-specific. Erosion would have a stronger effect compared with inundation, the effect of which depends on the interplay between the flood depth, the flow velocity and the element inundated. Cultural sites, which tend to be either archaeological or historical built heritage, will be affected by both erosion and flooding, while bio-cultural and natural areas are more likely to recover from episodic flooding. A partially flooded or eroded natural area may accommodate these disruptions and maintain ecological equilibrium, 
Table 2 | Country level projections of AHS exposure to the 100-year coastal extreme event by the end of the century, under moderate (RCP 4.5) and high emissions (RCP 8.5)

\begin{tabular}{|c|c|c|c|c|c|c|c|c|c|c|}
\hline \multirow[b]{2}{*}{ Country } & \multicolumn{3}{|c|}{ No. sites exposed } & \multicolumn{3}{|c|}{ Area exposed $\left(\mathrm{km}^{2}\right)$} & \multicolumn{3}{|c|}{ Percentage of country's sites exposed } & \multirow{2}{*}{$\begin{array}{l}\text { No. } \\
\text { sites }\end{array}$} \\
\hline & Baseline & $\begin{array}{l}\text { RCP } \\
4.5-2100\end{array}$ & $\begin{array}{l}\text { RCP } \\
8.5-2100\end{array}$ & Baseline & $\begin{array}{l}\text { RCP } \\
4.5-2100\end{array}$ & $\begin{array}{l}\text { RCP } \\
8.5-2100\end{array}$ & Baseline & RCP 4.5-2100 & $\begin{array}{l}\text { RCP } \\
8.5-2100\end{array}$ & \\
\hline BEN & $1(1-1)$ & $3(3-3)$ & $3(3-3)$ & $1(1-1)$ & $\begin{array}{l}402 \\
(349-570)\end{array}$ & $\begin{array}{l}503 \\
(406-803)\end{array}$ & $\begin{array}{l}20.0 \\
(20.0-20.0)\end{array}$ & $60.0(60.0-60.0)$ & $\begin{array}{l}60.0 \\
(60.0-60.0)\end{array}$ & 5 \\
\hline CMR & $0(0-0)$ & $3(3-3)$ & $3(3-3)$ & $0(0-0)$ & $37(23-67)$ & $59(33-171)$ & $0.0(0.0-0.0)$ & $\begin{array}{l}100.0 \\
(100.0-100.0)\end{array}$ & $\begin{array}{l}100.0 \\
(100.0-100.0)\end{array}$ & 3 \\
\hline COG & $0(0-0)$ & $5(5-5)$ & $5(5-5)$ & $0(0-0)$ & $105(66-195)$ & $190(91-439)$ & $0.0(0.0-0.0)$ & $\begin{array}{l}100.0 \\
(100.0-100.0)\end{array}$ & $\begin{array}{l}100.0 \\
(100.0-100.0)\end{array}$ & 5 \\
\hline DJ & $1(1-1)$ & $5(5-5)$ & $5(5-5)$ & $0(0-0)$ & $31(28-39)$ & $39(32-55)$ & $\begin{array}{l}20.0 \\
(20.0-20.0)\end{array}$ & $\begin{array}{l}100.0 \\
(100.0-100.0)\end{array}$ & $\begin{array}{l}100.0 \\
(100.0-100.0)\end{array}$ & 5 \\
\hline DZA & $2(2-2)$ & $8(8-9)$ & $9(8-10)$ & $85(85-85)$ & $195(145-211)$ & $\begin{array}{l}266 \\
(181-308)\end{array}$ & $9.5(9.5-9.5)$ & $38.1(38.1-42.9)$ & $\begin{array}{l}42.9 \\
(38.1-47.6)\end{array}$ & 21 \\
\hline EGY & $4(4-4)$ & $8(8-8)$ & $8(8-8)$ & $78(78-78)$ & $156(112-192)$ & $\begin{array}{l}201 \\
(148-221)\end{array}$ & $\begin{array}{l}23.5 \\
(23.5-23.5)\end{array}$ & $47.1(47.1-47.1)$ & $\begin{array}{l}47.1 \\
(47.1-47.1)\end{array}$ & 17 \\
\hline ESH & $1(1-1)$ & $4(4-4)$ & $4(4-4)$ & $6(6-6)$ & $71(56-127)$ & $88(67-165)$ & $\begin{array}{l}25.0 \\
(25.0-25.0)\end{array}$ & $\begin{array}{l}100.0 \\
(100.0-100.0)\end{array}$ & $\begin{array}{l}100.0 \\
(100.0-100.0)\end{array}$ & 4 \\
\hline GAB & $0(0-0)$ & $6(6-6)$ & $6(6-6)$ & $0(0-0)$ & $\begin{array}{l}205 \\
(93-350)\end{array}$ & $\begin{array}{l}344 \\
(178-611)\end{array}$ & $0.0(0.0-0.0)$ & $\begin{array}{l}100.0 \\
(100.0-100.0)\end{array}$ & $\begin{array}{l}100.0 \\
(100.0-100.0)\end{array}$ & 6 \\
\hline KEN & $2(2-2)$ & $2(2-2)$ & $2(2-3)$ & $\begin{array}{l}285 \\
(285-285)\end{array}$ & $\begin{array}{l}822 \\
(689-1,075)\end{array}$ & $\begin{array}{l}1,028 \\
(756-1,246)\end{array}$ & $\begin{array}{l}40.0 \\
(40.0-40.0)\end{array}$ & $40.0(40.0-40.0)$ & $\begin{array}{l}40.0 \\
(40.0-60.0)\end{array}$ & 5 \\
\hline LBY & $1(1-1)$ & $3(3-3)$ & $3(3-3)$ & $3(3-3)$ & $4(3-5)$ & $5(4-6)$ & $\begin{array}{l}33.3 \\
(33.3-33.3)\end{array}$ & $\begin{array}{l}100.0 \\
(100.0-100.0)\end{array}$ & $\begin{array}{l}100.0 \\
(100.0-100.0)\end{array}$ & 3 \\
\hline MAR & $7(7-7)$ & $21(21-22)$ & $23(22-23)$ & $72(72-72)$ & $\begin{array}{l}260 \\
(236-347)\end{array}$ & $\begin{array}{l}332 \\
(278-385)\end{array}$ & $\begin{array}{l}26.9 \\
(26.9-26.9)\end{array}$ & $80.8(80.8-84.6)$ & $\begin{array}{l}88.5 \\
(84.6-88.5)\end{array}$ & 26 \\
\hline MDG & $2(2-2)$ & $11(11-11)$ & $11(11-13)$ & $51(51-51)$ & $\begin{array}{l}400 \\
(274-610)\end{array}$ & $\begin{array}{l}501 \\
(319-659)\end{array}$ & $11.1(11.1-11.1)$ & $61.1(61.1-61.1)$ & $\begin{array}{l}61.1 \\
(61.1-72.2)\end{array}$ & 18 \\
\hline $\mathrm{MOZ}$ & $2(2-2)$ & $4(4-4)$ & $4(4-4)$ & $5(5-5)$ & $\begin{array}{l}5,683 \\
(4,235-7,880)\end{array}$ & $\begin{array}{l}7,135(4,682- \\
8,954)\end{array}$ & $\begin{array}{l}50.0 \\
(50.0-50.0)\end{array}$ & $\begin{array}{l}100.0 \\
(100.0-100.0)\end{array}$ & $\begin{array}{l}100.0 \\
(100.0-100.0)\end{array}$ & 4 \\
\hline MRT & $1(1-1)$ & $4(4-4)$ & $4(4-4)$ & $\begin{array}{l}131 \\
(131-131)\end{array}$ & $\begin{array}{l}1,764 \\
(1,665-2,137)\end{array}$ & $\begin{array}{l}2,115 \\
(1,828-2,555)\end{array}$ & $\begin{array}{l}25.0 \\
(25.0-25.0)\end{array}$ & $\begin{array}{l}100.0 \\
(100.0-100.0)\end{array}$ & $\begin{array}{l}100.0 \\
(100.0-100.0)\end{array}$ & 4 \\
\hline NAM & $3(3-3)$ & $5(5-5)$ & $5(5-5)$ & $31(31-31)$ & $\begin{array}{l}273 \\
(251-331)\end{array}$ & $\begin{array}{l}332 \\
(299-377)\end{array}$ & $\begin{array}{l}60.0 \\
(60.0-60.0)\end{array}$ & $\begin{array}{l}100.0 \\
(100.0-100.0)\end{array}$ & $\begin{array}{l}100.0 \\
(100.0-100.0)\end{array}$ & 5 \\
\hline SEN & $7(7-7)$ & $10(10-11)$ & $11(10-11)$ & $\begin{array}{l}786 \\
(786-786)\end{array}$ & $\begin{array}{l}2,291 \\
(2,138-2,816)\end{array}$ & $\begin{array}{l}2,796 \\
(2,394-3,318)\end{array}$ & $\begin{array}{l}53.8 \\
(53.8-53.8)\end{array}$ & $76.9(76.9-84.6)$ & $\begin{array}{l}84.6 \\
(76.9-84.6)\end{array}$ & 13 \\
\hline TUN & $7(7-7)$ & $20(20-21)$ & $21(20-24)$ & $42(42-42)$ & $\begin{array}{l}178 \\
(135-229)\end{array}$ & $\begin{array}{l}222 \\
(165-555)\end{array}$ & $\begin{array}{l}20.6 \\
(20.6-20.6)\end{array}$ & $58.8(58.8-61.8)$ & $\begin{array}{l}61.8 \\
(58.8-70.6)\end{array}$ & 34 \\
\hline ZAF & $2(2-2)$ & $14(14-15)$ & $15(14-15)$ & $5(5-5)$ & $\begin{array}{l}584 \\
(537-759)\end{array}$ & $\begin{array}{l}734 \\
(595-845)\end{array}$ & $\begin{array}{l}10.0 \\
(10.0-10.0)\end{array}$ & $70.0(70.0-75.0)$ & $\begin{array}{l}75.0 \\
(70.0-75.0)\end{array}$ & 20 \\
\hline
\end{tabular}

The number of sites and area exposed, as well as total number of sites and the percentage of which is exposed, are shown. Values express the median, combined with the very likely range (5th-95th percentiles) in brackets. Owing to space restrictions, only countries with the highest projected increase in heritage exposure are shown.

either by migrating landwards, or even while shrinking, in the frequent case that retreat is constrained by coastal development.

How much area a heritage site can lose to flooding and erosion and still maintain its value (for example, cultural, ecological, Indigenous and economic) is a question of growing importance for all protected areas and World Heritage Sites, and demands site-specific local studies. The same applies to the capacity of natural coastal systems to adapt and absorb other external shocks, such as changes in salinity, which remains unknown ${ }^{17}$.

Anthropogenic modification of coastal processes will also affect natural systems' responses to shoreline change. For example, in the Bight of Benin, West Africa, the construction of dams on the Volta River, combined with lower rainfall, contributed to a decrease in sediments on the coast, thereby increasing the effects of coastal flooding and erosion ${ }^{33}$. Several sandy beaches of the continent are naturally protected by ecological elements, such as coral reefs, seagrass and mangroves ${ }^{34-36}$. However, the fate of coral reefs depends on future marine heatwaves ${ }^{37}$ and ocean acidification trends ${ }^{38}$ - both of which are expected to increase all around the continent-while mangroves are also threatened by rising seas. For example, five species of mangrove are listed among biota likely to become locally extinct in Ghana, if rising seas outpace the rate of forest migration ${ }^{39}$. In Central Africa (Cameroon) as well as in other regions, mangrove logging and anthropization also accelerates these effects ${ }^{40}$. The eastern African coast, considered a region of high diversity of seagrass ${ }^{41}$, is subject to frequent anthropogenic disturbance, resulting in the loss of about $21 \%$ of Kenya's seagrass cover between 1986 and $2016^{42}$. Such transitions could have further indirect effects and weaken natural coastal protection, further exacerbating flood risk; with substantial social consequences ${ }^{43}$. 

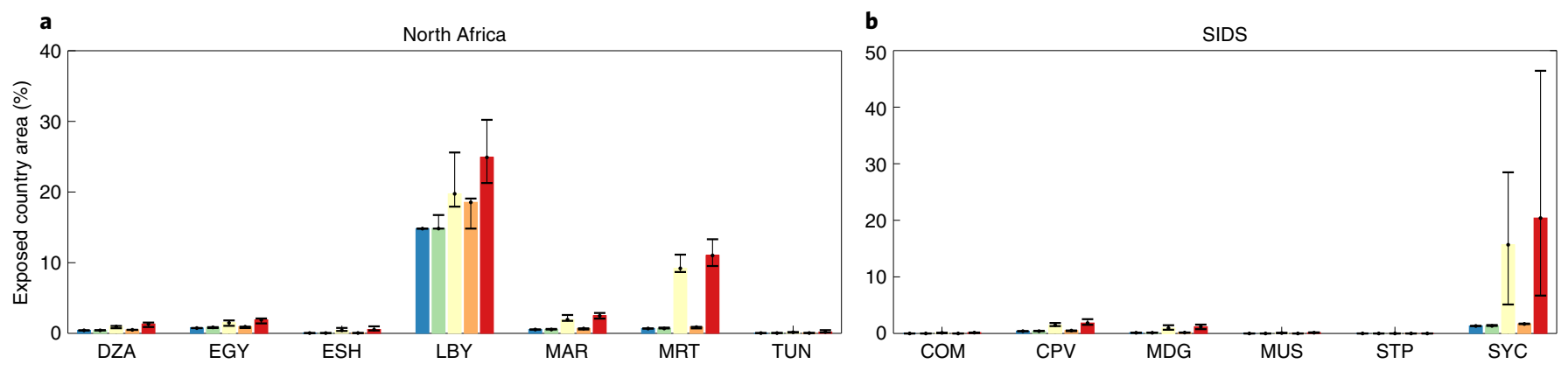

C
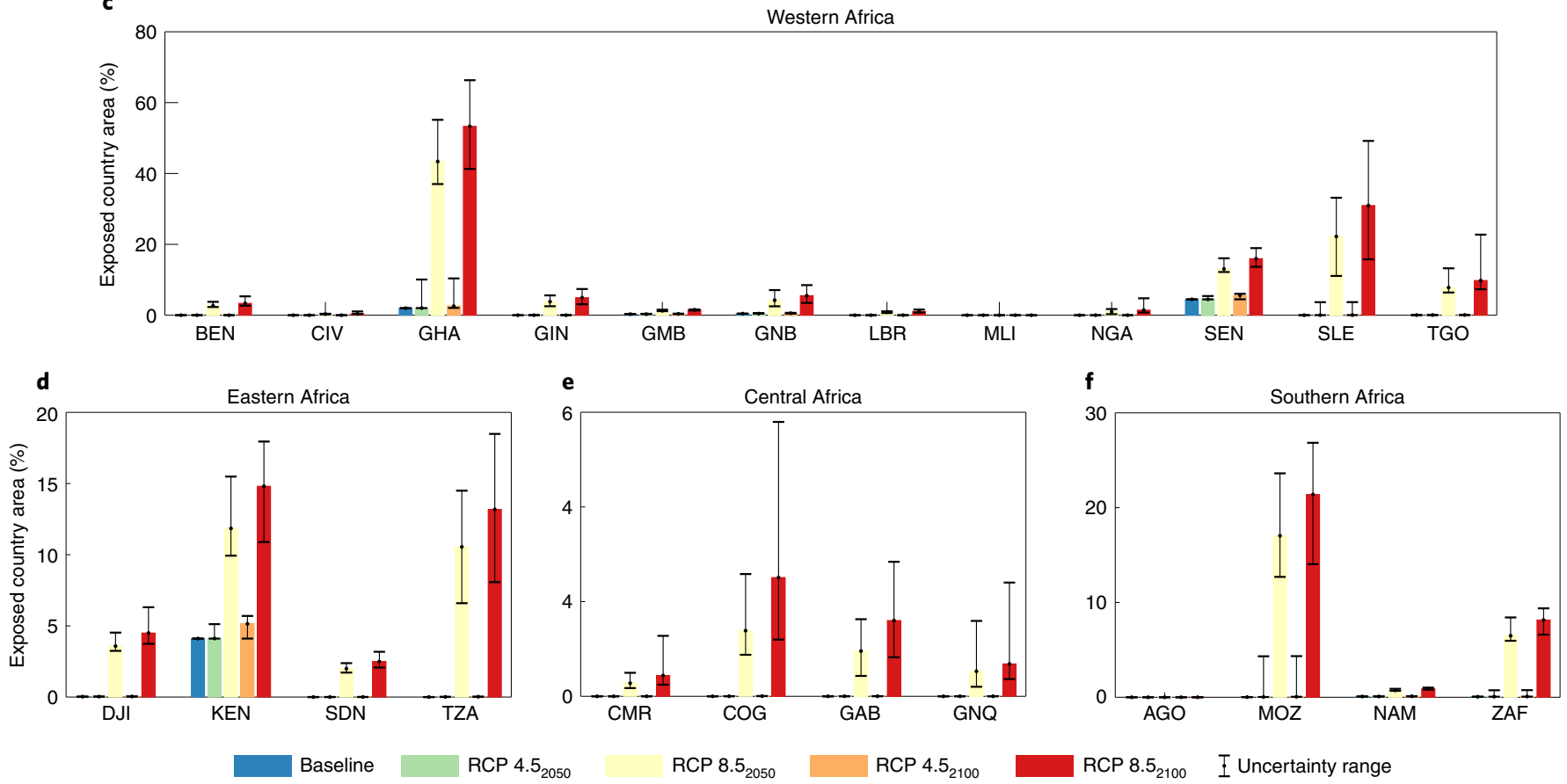

Fig. 4 | Country estimates of the percentage of the area of AHS affected by the 100-year coastal extreme event during the twenty-first century.

a-f, Projections are grouped in regional subplots for North Africa (a), SIDS (b), Western Africa (c), Eastern Africa (d), Central Africa (e) and Southern Africa (f), with blue indicating the baseline (2010) and green, yellow, orange and red corresponding to projections for the different emission pathways RCP 4.5 (green, orange) and RCP 8.5 (yellow, red), by 2050 and 2100, respectively. Thin bars indicate the very likely range (5th-95th percentiles).

Our findings help with prioritizing sites at risk and highlight the need for immediate protective action for AHS; the design of which requires in-depth local-scale assessments of vulnerability and adaptation options. For many cultural and natural sites, relocation or managed retreat might be the least favourable option due to intrinsic values of site locations and potential impacts on local communities $^{3}$. Coastal protection through the construction of breakwaters, groins and beach nourishment may be effective, where they are technologically and financially feasible. For example, protections to Qaitbay Citadel $(1,822)$, Egypt, have recently been reinforced ${ }^{44}$. However, such 'hard' protection strategies need to consider future sea levels and are known to distort the site's natural ecological and morphological equilibrium ${ }^{45}$. Hybrid protections that include ecological infrastructure, such as rock sills combined with saltmarshes, seagrasses or restored mangroves, may prove more effective ${ }^{17,45}$. Improving local and Indigenous governance, monitoring and evaluation, and broader land management actions, such as expanded buffer zones, can further provide enabling conditions for site protection that address existing vulnerabilities ${ }^{2,46,47}$.

As understanding of climate risk to heritage grows, there is potential for these exposure findings to raise public concern and mobilize rapid and ambitious greenhouse gas mitigation to reduce overall risk and potential loss and damage ${ }^{3}$. Future research needs to quantify climate risk to heritage more broadly, including risks to inland heritage across Africa. Knowledge is also needed on risks from a broader range of climate hazards, and particularly potential impacts from compound climate extremes. Finally, better understanding is needed of risks from responses to climate change that will also affect heritage ${ }^{48}$, such as migration, managed retreat, ecosystem-based adaptation and relocation.

\section{Online content}

Any methods, additional references, Nature Research reporting summaries, source data, extended data, supplementary information, acknowledgements, peer review information; details of author contributions and competing interests; and statements of data and code availability are available at https://doi.org/10.1038/ s41558-022-01280-1.

Received: 12 August 2021; Accepted: 5 January 2022;

Published online: 10 February 2022 


\section{References}

1. Operational Guidelines for the Implementation of the World Heritage Convention (UNESCO, 2012).

2. Pearson, J., Jackson, G. \& McNamara, K. E. Climate-driven losses to Indigenous and local knowledge and cultural heritage. Anthr. Rev. https://doi.org/10.1177/20530196211005482 (2021).

3. Reimann, L., Vafeidis, A. T., Brown, S., Hinkel, J. \& Tol, R. S. J. Mediterranean UNESCO World Heritage at risk from coastal flooding and erosion due to sea-level rise. Nat. Commun 9, 4161 (2018).

4. Marzeion, B. \& Levermann, A. Loss of cultural world heritage and currently inhabited places to sea-level rise. Environ. Res. Lett 9, 034001 (2014).

5. Sesana, E., Gagnon, A. S., Ciantelli, C., Cassar, J. \& Hughes, J. J. Climate change impacts on cultural heritage: a literature review. WIREs Clim. Change 12, e710 (2021).

6. Dangendorf, S. et al. Persistent acceleration in global sea-level rise since the 1960s. Nat. Clim. Change 9, 705-710 (2019).

7. Fasullo, J. T. \& Nerem, R. S. Altimeter-era emergence of the patterns of forced sea-level rise in climate models and implications for the future. Proc. Natl Acad. Sci. USA 115, 12944-12949 (2018).

8. Slater, T., Hogg, A. E. \& Mottram, R. Ice-sheet losses track high-end sea-level rise projections. Nat. Clim. Change 10, 879-881 (2020).

9. Nicholls, R. J. et al. A global analysis of subsidence, relative sea-level change and coastal flood exposure. Nat. Clim. Change 11, 338-342 (2021).

10. Meucci, A., Young, I. R., Hemer, M., Kirezci, E. \& Ranasinghe, R. Projected 21st century changes in extreme wind-wave events. Sci. Adv. 6, eaaz7295 (2020).

11. Bevacqua, E. et al. More meteorological events that drive compound coastal flooding are projected under climate change. Commun. Earth Environ. 1, 47 (2020).

12. Kirezci, E. et al. Projections of global-scale extreme sea levels and resulting episodic coastal flooding over the 21st century. Sci. Rep. 10, 11629 (2020).

13. Kulp, S. A. \& Strauss, B. H. New elevation data triple estimates of global vulnerability to sea-level rise and coastal flooding. Nat. Commun 10, 4844 (2019).

14. Vousdoukas, M. I. et al. Sandy coastlines under threat of erosion. Nat. Clim. Change 10, 260-263 (2020).

15. Hinkel, J. et al. Coastal flood damage and adaptation costs under 21st century sea-level rise. Proc. Natl Acad. Sci. USA 111, 3292-3297 (2014).

16. Vousdoukas, M. I. et al. Economic motivation for raising coastal flood defenses in Europe. Nat. Commun. 11, 2119 (2020).

17. Brito, J. C. \& Naia, M. Coping with sea-level rise in African protected areas: priorities for action and adaptation measures. BioScience 70, 924-932 (2020).

18. Ramsar Sites and the List of Wetlands of International Importance (Ramsar Sites Information Service, accessed 1 June 2020); https://rsis.ramsar.org/

19. World Heritage List (UNESCO, accessed 1 September 2020); https://whc unesco.org/en/list/

20. Tentative Lists (UNESCO, accessed 1 June 2020); https://whc.unesco.org/en/ tentativelists/

21. Convention on Wetlands of International Importance Especially as Waterfowl Habitat (The Ramsar Convention Secretariat, 1971)

22. Vousdoukas, M. I. et al. Developments in large-scale coastal flood hazard mapping. Nat. Hazards Earth Syst. Sci. 16, 1841-1853 (2016).

23. Abdelaziz, M. \& Elsayed, M. Underwater photogrammetry Digital Surface Model (DSM) of the submerged site of the ancient lighthouse near Qaitbay Fort in Alexandria, Egypt. ISPRS Archives XLII-2/W10, 1-8 (2019).

24. Green Climate Fund 2019 Annual Performance Report for FP053: Enhancing Climate Change Adaptation in the North Coast and Nile Delta Regions in Egypt (United Nations Development Programme, 2020).

25. Hamerlynck, O., Duvail, S., Ould Messaoud, B. \& Benmergui, M. in Coastal Ecosystems of West-Africa: Biological Diversity Conservation Resources (ed. Symoens, J.) 195-210 (FFRSA, 2005).

26. Duvail, S. \& Hamerlynck, O. Mitigation of negative ecological and socio-economic impacts of the Diama Dam on the Senegal River Delta wetland (Mauritania), using a model based decision support system. Hydrol. Earth Syst. Sci. 7, 133-146 (2003).

27. Ofosu, S. A., Adjei, K. A. \& Odai, S. N. Ecological vulnerability of the Densu River Basin due to land use change and climate variability. Cogent Eng. 7, 1735714 (2020).
28. Aman, A. et al. Physical forcing induced coastal vulnerability along the Gulf of Guinea. J. Environ. Prot. 10, 1194-1211 (2019).

29. Mensah, C., Kabo-bah, A. T. \& Mortey, E. Assessing the effects of climate change on sea level rise along the Gulf of Guinea. J. Energy Nat. Resour. Manag 4, 15-22 (2017).

30. Priority Africa: Sustainable Development and World Heritage (UNESCO, 2019).

31. Ekblom, A., Shoemaker, A., Gillson, L., Lane, P. \& Lindholm, K.-J. Conservation through biocultural heritage-examples from sub-Saharan Africa. Land 8, 5 (2019).

32. Ndoro, W. \& Chirikure, S. in Managing Heritage in Africa: Who Cares? (eds Ndoro, W. et al.) 237-250 (Routledge, 2018).

33. Anthony, E. J. et al. Response of the Bight of Benin (Gulf of Guinea, West Africa) coastline to anthropogenic and natural forcing, part 2: sources and patterns of sediment supply, sediment cells, and recent shoreline change. Cont. Shelf Res. 173, 93-103 (2019).

34. Paul, M. The protection of sandy shores - can we afford to ignore the contribution of seagrass? Mar. Pollut. Bull. 134, 152-159 (2018).

35. Sabour, S., Brown, S., Nicholls, R., Haigh, I. \& Luijendijk, A. Multi-decadal shoreline change in coastal Natural World Heritage Sites - a global assessment. Environ. Res. Lett. 15, 104047 (2020).

36. Beck, M. W. et al. The global flood protection savings provided by coral reefs Nat. Commun. 9, 2186 (2018).

37. Frölicher, T. L., Fischer, E. M. \& Gruber, N. Marine heatwaves under global warming. Nature 560, 360-364 (2018).

38. Jiang, L.-Q., Carter, B. R., Feely, R. A., Lauvset, S. K. \& Olsen, A. Surface ocean $\mathrm{pH}$ and buffer capacity: past, present and future. Sci. Rep. 9, 18624 (2019).

39. Armah, A., Wiafe, G. \& Kpelle, D. in Climate Change and Africa (ed. Low, P.) 204-217 (Cambridge Univ. Press, 2005).

40. Fossi Fotsi, Y., Pouvreau, N., Breno,n I., Onguene, R. \& Etame, J. Temporal (1948-2012) and dynamic evolution of the Wouri estuary coastline within the Gulf of Guinea. J. Mar. Sci. Eng. 7, 343 (2019).

41. Bandeira, S. O. \& Björk, M. Seagrass research in the eastern Africa region: emphasis on diversity, ecology and ecophysiology. S. Afr. J. Bot. 67, 420-425 (2001)

42. Harcourt, W. D., Briers, R. A. \& Huxham, M. The thin(ning) green line? Investigating changes in Kenya's seagrass coverage. Biol. Lett. 14, 20180227 (2018)

43. Ballesteros, C. \& Esteves, L. S. Integrated assessment of coastal exposure and social vulnerability to coastal hazards in East Africa. Estuaries Coasts https://doi.org/10.1007/s12237-021-00930-5 (2021)

44. Kamal, I., Fekri, M., AbouEl-Magd, I. \& Soliman, N. Mapping the impacts of projected sea-level rise on cultural heritage sites in Egypt: case study (Alexandria). J. Faculty Tour. Hotels 5, 1-20 (2021).

45. Morris, R. L., Boxshall, A. \& Swearer, S. E. Climate-resilient coasts require diverse defence solutions. Nat. Clim. Change 10, 485-487 (2020).

46. Morrison, T. H. et al. Political dynamics and governance of World Heritage ecosystems. Nat. Sustain. 3, 947-955 (2020).

47. Carmichael, B. et al. A methodology for the assessment of climate change adaptation options for cultural heritage sites. Climate 8, 88 (2016).

48. Simpson, N. P. et al. A framework for complex climate change risk assessment. One Earth 4, 489-501 (2021).

Publisher's note Springer Nature remains neutral with regard to jurisdictional claims in published maps and institutional affiliations.

Open Access This article is licensed under a Creative Commons

Attribution 4.0 International License, which permits use, sharing, adaptation, distribution and reproduction in any medium or format, as long as you give appropriate credit to the original author(s) and the source, provide a link to the Creative Commons license, and indicate if changes were made. The images or other third party material in this article are included in the article's Creative Commons license, unless indicated otherwise in a credit line to the material. If material is not included in the article's Creative Commons license and your intended use is not permitted by statutory regulation or exceeds the permitted use, you will need to obtain permission directly from the copyright holder. To view a copy of this license, visit http://creativecommons. org/licenses/by/4.0/.

(C) The Author(s) 2022 


\section{Methods}

General. We assess the exposure of African natural and cultural heritage sites to coastal hazards (specifically coastal floods and erosion) during the twenty-first century. We generate a database of heritage sites in Africa by compiling, validating and correcting existing information. Then, we overlay the heritage dataset with hazard maps describing the evolution of coastal flooding and sandy beach erosion during the twenty-first century. We use two greenhouse gas emission scenarios: a moderate (RCP 4.5) and a high emissions (RCP 8.5) scenario ${ }^{49}$, both resulting in global warming above the Paris Agreement long-term temperature target of $2{ }^{\circ} \mathrm{C}$.

Heritage sites definition. We consider all African sites included in the UNESCO World Heritage List of $2020^{19}$ and the Ramsar Sites Information Service ${ }^{18,21}$. Poor representation of African sites on the World Heritage List is a known issue ${ }^{50,51}$, therefore we also consider African sites included in the UNESCO World Heritage Tentative List ${ }^{20}$. These sites have been proposed, recognized and endorsed as holding potential 'Outstanding Universal Value'. Our study focusses on 71 cultural and 213 natural heritage sites found within 38 of the 39 African countries with a coastline ${ }^{52}$

Accurate maps and coordinates of most Ramsar sites are available in the official database; in contrast to World Heritage Sites, which are not always described by accurate maps and coordinates, often intentionally, to protect fragile heritage sites from looting. In addition, sites on the World Heritage Tentative List are not provided with maps or coordinates. The World Database on Protected Areas ${ }^{5}$ was loaded into a geographic information system to identify missing polygons for Ramsar and Natural World Heritage Sites. Maps of sites were overlaid onto Google Earth using the image overlay function ${ }^{54-56}$, allowing delineation of each site's boundaries. When sites were not identifiable, due to either land cover or missing/ inaccurate information, we used historical imagery and/or published literature to delineate the site accurately $y^{57,58}$. This resulted in a polygon shapefile containing the master table of all sites (see Extended Data Fig. 1 and the publicly available dataset in the Data availability section). The database includes the names and locations of the sites, their officially designated heritage site number and their geospatial outline, as well as the site area and the mean, minimum and maximum elevation of each site. The total area of all the sites of interest is $512,757 \mathrm{~km}^{2}$. In the present analysis of coastal exposure, sites found at elevations below $50 \mathrm{~m}$ are included, this is a conservative inclusion criteria to ensure all sites potentially exposed to rising seas are included. The filtering was done using elevation data from the 3 arcsec GLO-90 digital elevation model (DEM) available from the Copernicus services ${ }^{59}$, and the threshold elevation is sufficiently high to ensure that no site is erroneously excluded due to vertical bias of the DEM (in the worst case, a few metres).

Heritage site delineations used here are constrained to the physical characteristics of the site that were remotely sensed for the purpose of coastal flood analysis. However, heritage can be framed in multiple ways and is defined differently across disciplines. Given the variety of ways to perceive and experience heritage, we recognize that a polygon created in a geographic information system does not reflect the full value of heritage. The latter includes intangible characteristics and plural viewpoints on heritage type and extent, particularly for local and Indigenous communities to which many of these heritage sites belong.

Sea-level rise, tides, waves and storm surges. Hindcasts of waves and storm surges (1980-2015) are obtained through dynamic simulations forced by the European Centre for Medium-Range Weather Forecasts (ECMWF) ERA-Interim Reanalysis atmospheric conditions. Storm surges are simulated using the DFLOW FM model $^{60}$, and the waves using the third-generation spectral wave model WW $3^{61,62}$ Both models have been extensively validated with detailed information provided in the references above, as well as in ref. ${ }^{60}$. Tropical cyclones, not fully represented by global reanalyses ${ }^{63}$, have been simulated by the DFLOW FM model forced by the IBTrACS best-track archive ${ }^{64}$. Cyclone effects on the waves are considered using the peak maxima of significant wave heights $H_{s}$ measured by altimeter data provided by six different satellites ${ }^{65}$ : ERS-2, ENVISAT, Jason 1 and 2, Cryosat 2 and SARAL-AltiKa.

Present-day tidal elevations $\left(\eta_{\text {tide }}\right)$ are obtained from the FES2014 model ${ }^{66}$. Following the approach of ref. ${ }^{60}$, the high-tide water level is considered, taking into account the range due to the spring-neap tide cycle. Probabilistic sea-level rise projections from ref. ${ }^{67}$ and DFLOW $\mathrm{FM}^{68}$ are then used to assess changes in global tidal elevations due to changing sea levels ${ }^{60}$. Simulations of waves and storm surges until the end of the century are forced by outputs from six CMIP5 climate models ${ }^{61,62}$

Coastal inundation. Inundation maps along the entire coast of Africa are obtained following the approach presented in ref. ${ }^{22}$, using the Lisflood-ACC (LFP) model ${ }^{69,70}$. Simulations are based on the GLO-90 DEM $^{59}$. Land hydraulic roughness is derived from land-use maps ${ }^{71}$. The inundation modelling takes place over coastal segments distributed along the coast, with spacing of $25 \mathrm{~km}$ with each other and extending up to $200 \mathrm{~km}$ landwards. The simulations are forced by ESLs defined as the combination of mean sea level, astronomical tide $\left(\eta_{\text {tide }}\right)$ and meteorological tide $\left(\eta_{\mathrm{CE}}\right.$; that is, the combination of storm surge and the wave setup ${ }^{72}$ ). All components are combined in Monte Carlo simulations, which allow quantifying the full range of uncertainty and produce probability density functions of ESLs. In this analysis, we focus on the median value of the 100-year event, obtained from non-stationary extreme value analysis ${ }^{73}$

A known limitation of flood risk analyses, especially at regional scale and beyond, is the absence of information on coastal flood protection. As a result, previous studies either don't consider any protection standards ${ }^{12}$, or consider arbitrary ones, based on criteria such as the population, gross domestic product, and gross domestic product per capita, among others ${ }^{74}$. As our analysis is focussing on the 100-year event, we assume that in none of the studied sites is such a protection standard implemented.

To assess heritage sites exposed to coastal flooding, we overlay the heritage site polygons with the inundation maps for each RCP (that is, RCP 4.5 and RCP 8.5) and time step studied (that is, 2010, 2030, 2050, 2070, 2090 and 2100). Given that some sites are partially under water even under normal (that is, non-ESL) conditions, we exclude areas inundated by the present-day high-tide water level. Subsequently, we calculate the area flooded $\left(\right.$ in $\mathrm{km}^{2}$ ) and the share of the site flooded (in \%) in each scenario and time step, based on ref. ${ }^{3}$.

Coastal erosion. Projections of shoreline change driven from ambient factors, relative sea-level rise and episodic erosion during extreme storms are available from ref. ${ }^{14}$. The projections are probabilistic, providing full probability density functions every 10 years until 2100. Shoreline change is the combined result of three components: (1) ambient shoreline dynamics driven by long-term hydrodynamic, geological and anthropic factors ${ }^{75,76}$; (2) shoreline retreat due to relative sea-level rise, estimated using a modified version of the Bruun rule ${ }^{14}$; and (3) episodic erosion during extreme storms (as with the floods, we focus on the 100-year event), estimated after detecting extreme events from global wave projections datasets and simulating beach profile response at each global location (the analysis includes millions of simulations and is described in detail in ref. ${ }^{14}$.

The existing projections of ref. ${ }^{14}$ express potential shoreline change, assuming infinite amount of sediment supply and accommodating space for coastal retreat at the backshore. As a result, additional effort was used to identify where and to what extent shoreline retreat in the vicinity of heritage sites would be interrupted by the presence of non-erodible features (for example, seawalls, revetments) and other specific geological conditions. Starting from the dataset on the spatial distribution of sandy beaches along the African coastline from ref. ${ }^{76}$, we consider additional information to identify which sites are actually exposed to coastal erosion. The Global Lithological Map ${ }^{77}$ is the most accurate dataset describing the properties of surface rocks worldwide and is used to identify rocky coastlines, while additional natural and man-made obstacles to shoreline retreat were identified through carefully inspecting the time history of satellite images from Google Earth at all sites. At beaches where obstructions to shoreline retreat were identified, the retreat projected in ref. ${ }^{14}$ was limited to the erodible area seaward of the obstruction. After the above processing, we identify 6 cultural and 55 natural sites that are considered as potentially exposed to coastal erosion.

Combined coastal hazard. The above steps result in estimates of the exposed area to coastal flooding and erosion for all the combinations of heritage sites, emission scenarios, years and percentiles $(1,5,16,50,84,95$ and 99). For each case, we consider the total affected area as the maximum of the area exposed from each of the two hazards. We also estimate the percentage of the total area exposed $($ EA\%), defining five classes of exposure: no exposure, small $($ EA $\%<25)$, moderate $(25<\mathrm{EA} \%<50)$, high $(50<\mathrm{EA} \%<75)$ and very high $(\mathrm{EA} \%>75)$.

Apart from discussing the results at site level, we also group at country, as well as regional levels. We also focus on the median, 5th and 95th percentiles (very likely range), under the two emissions scenarios considered here.

Limitations/foresight. Existing studies have shown that heritage can be exposed to several natural hazards such as fires, river floods and earthquakes, among others ${ }^{5,78}$. Also, there are some previous efforts to quantify the exposure through indicators (for example, https://cvi-heritage.org). In this continental scale assessment, we focus on only the coastal hazard exposure of AHS, trying to provide the most accurate, quantitative information as possible given the available datasets. We use the exposed area as indicator, since the available datasets do not allow quantifying other proxies, such as economic losses. Important to heritage valuation, there is a lack of data on the intangible qualities of AHS, such as Indigenous knowledge, making assessment of their exposure and potential loss or damage from climate change not possible at this scale of research. In addition, we lack the information on how components are distributed inside each site, and therefore we cannot quantify to what extent the impact of exposure among different areas of the same site varies. The above would be very interesting directions for future research ${ }^{79}$, but there are no available data allowing quantification of the economic value of AHS.

As do most global assessments, our analysis contains inevitable limitations in terms of methodological abstraction and data accuracy/resolution. DEMs are known to be a dominant factor of uncertainty ${ }^{80,81}$ and there are several publicly available global datasets that aim to improve that aspect ${ }^{82-84}$. In this analysis we use GLO-90, which has been recently published by the European Union's Earth observation programme. GLO-90 combines several existing DEMs (https:// spacedata.copernicus.eu/web/cscda/dataset-details?articleId=394198), among which are elevation data provided from X-band radar, proven to be capable of 
achieving better accuracy, compared with Shuttle Radar Topography Mission (SRTM) variants. Therefore, we are confident that GLO-90 is a reliable choice for the DEM.

Another assumption is that we consider coastal flooding independently from river flooding or precipitation, despite the fact that these factors, when acting together with non-climatic threats ${ }^{85}$, can have a larger compound effect ${ }^{11}$. However, despite recent advances ${ }^{86}$, incorporating all the above components in a pan-African assessment is still challenging. For that reason, we focus only on marine flooding, omitting terrestrial and groundwater flows, as it is also unknown to what extent the latter would affect inundation along AHS. Future research is needed to quantify the potential role of human abstraction from coastal groundwater sources on subsidence and salinity at the site level, for example, as has been shown to be the case in Lamu Old Town, Kenya, and thereby the integrity of AHS ${ }^{87}$

Predicting morphological evolution in the highly dynamic and complex coastal zone is challenging and here we build our methodology on recently published projections ${ }^{14}$. The original shoreline change projections, although introducing several improvements, come with certain well-known limitations ${ }^{88,89}$. Several of them, such as the assumption of infinite accommodating space in the case of erosion, have been largely mitigated through post-processing, by considering information about the lithology and erodability characteristics of each site. However, our community is still far from being able to accurately forecast long-term coastal erosion, especially as this is increasingly becoming more related to human activity than natural processes ${ }^{75}$. Therefore, the presented findings should be always considered as a first-pass continental assessment of AHS exposure to coastal hazards not precise quantitative estimates for each site, but rather a general overview of future challenges, allowing spatial and temporal comparisons. We are also confident that the publicly available data presented here will facilitate further efforts to bridge significant knowledge gaps on the fate of AHS under a changing climate.

\section{Data availability}

The models and datasets presented are part of the integrated risk assessment tool LISCoAsT (Large Scale Integrated Sea-level and Coastal Assessment Tool) developed by the Joint Research Centre of the European Commission. The African heritage sites list, as well as the coastal hazard assessment data, are available through the LISCoAsT repository of the Joint Research Centre data collection (http://data.jrc.ec.europa.eu/collection/LISCOAST) from https://data.jrc. ec.europa.eu/dataset/31e2737e-2059-4f47-b088-16db7a09a555. Heritage sites can be identified by their designated name and number in the data, and the centroid of the site is provided. We do not provide the polygons showing the extent of each site due to data sensitivities, but these can be provided by the corresponding authors on reasonable request for non-commercial use.

\section{Code availability}

The code that supported the findings of this study is available on reasonable request from the corresponding authors.

\section{References}

49. Meinshausen, M. et al. The RCP greenhouse gas concentrations and their extensions from 1765 to 2300. Clim. Change 109, 213 (2011).

50. Breen, C. Advocacy, international development and World Heritage Sites in sub-Saharan Africa. World Archaeol. 39, 355-370 (2007).

51. Howard, P. C. \& Bertzky, B. Natural World Heritage in Africa: Progress and Prospects (BIOPAMA Programme, IUCN Regional Office for Eastern and Southern Africa (ESARO) and IUCN Regional Office for West and Central Africa (PACO), 2020).

52. Member States (African Union, accessed 1 September 2020); https://au.int/en/ member_states/countryprofiles2

53. The World Database on Protected Areas (WDPA) (IUCN and UNEP-WCMC, accessed 1 September 2020); https://globil-panda.opendata.arcgis.com/dataset s/61cde74cf99645b7b2c30212514ddae5_1?geometry=35.859 $\% 2 \mathrm{C}-88.664 \% 2 \mathrm{C}-35.859 \% 2 \mathrm{C} 88.173$

54. Luo, L. et al. Google Earth as a powerful tool for archaeological and cultural heritage applications: a review. Remote Sens. 10, 1558 (2018).

55. Kaimaris, D., Georgoula, O., Patias, P. \& Stylianidis, E. Comparative analysis on the archaeological content of imagery from Google Earth. J. Cult. Herit. 12, 263-269 (2011).

56. Luo, L. et al. Low-cost archaeological investigation and rapid mapping of ancient stone tidal weirs in the Penghu archipelago using Google Earth. Sustainability 11, 4536 (2019).

57. Creating Image Overlays in Google Earth Desktop (Google Earth Outreach, accessed 2 September 2020); https://www.google.com/earth/outreach/learn/ creating-photos-image-overlays-in-google-earth/

58. Historical Maps: Making Map Overlays (University of Pennsylvania, accessed 2 September 2020); https://guides.library.upenn.edu/historical_maps/ mapoverlays

59. Copernicus Digital Elevation Model Product Handbook (Airbus, 2020).

60. Vousdoukas, M. I. et al. Global probabilistic projections of extreme sea levels show intensification of coastal flood hazard. Nat. Commun. 9, 2360 (2018).
61. Mentaschi, L., Vousdoukas, M. I., Voukouvalas, E., Dosio, A. \& Feyen, L. Global changes of extreme coastal wave energy fluxes triggered by intensified teleconnection patterns. Geophys. Res. Lett. 44, 2416-2426 (2017).

62. Vousdoukas, M. I., Mentaschi, L., Voukouvalas, E., Verlaan, M. \& Feyen, L. Extreme sea levels on the rise along Europe's coasts. Earths Future 5, 304-323 (2017).

63. Hodges, K., Cobb, A. \& Vidale, P. L. How well are tropical cyclones represented in reanalysis datasets? J. Clim. 30, 5243-5264 (2017).

64. Knapp, K. R., Kruk, M. C., Levinson, D. H., Diamond, H. J. \& Neumann, C. J. The International Best Track Archive for Climate Stewardship (IBTrACS). Bull. Am. Meteorol. Soc. 91, 363-376 (2010).

65. Queffeulou, P. \& Croizé-Fillon, D. Global Altimeter SWH Data Set (Laboratoire d'Océanographie Spatiale, IFREMER, 2014).

66. Lyard, F., Allain, D., Cancet, M., Carrere, L. \& Picot, N. FES2014 global ocean tide atlas: design and performance. Ocean Sci 17, 615-649 (2021).

67. Jevrejeva, S., Jackson, L. P., Riva, R. E. M., Grinsted, A. \& Moore, J. C. Coastal sea level rise with warming above $2^{\circ}$ C. Proc. Natl Acad. Sci. USA 113, 13342-13347 (2016).

68. Muis, S., Verlaan, M., Winsemius, H. C., Aerts, J. C. J. H. \& Ward, P. J. A global reanalysis of storm surges and extreme sea levels. Nat. Commun. 7, 11969 (2016).

69. Neal, J. et al. Evaluating a new LISFLOOD-FP formulation with data from the summer 2007 floods in Tewkesbury, UK. J. Flood Risk Manag. 4, 88-95 (2011).

70. Bates, P. D., Horritt, M. S. \& Fewtrell, T. J. A simple inertial formulation of the shallow water equations for efficient two-dimensional flood inundation modelling. J. Hydrol. 387, 33-45 (2010).

71. ESA CCI Land Cover Time-Series v2.0.7 (1992-2015) (European Space Agency, 2010); http://maps.elie.ucl.ac.be/CCI/viewer/index.php

72. Coastal Engineering Manual (US Army Corps of Engineers, 2002).

73. Mentaschi, L. et al. Non-stationary extreme value analysis: a simplified approach for Earth science applications. Hydrol. Earth Syst. Sci. Discuss. 2016, 1-38 (2016).

74. Scussolini, P. et al. FLOPROS: an evolving global database of flood protection standards. Nat. Hazards Earth Syst. Sci. 16, 1049-1061 (2016).

75. Mentaschi, L., Vousdoukas, M. I., Pekel, J.-F., Voukouvalas, E. \& Feyen, L. Global long-term observations of coastal erosion and accretion. Sci. Rep. 8, 12876 (2018).

76. Luijendijk, A. et al. The state of the world's beaches. Sci. Rep. 8, 6641 (2018).

77. Hartmann, J. \& Moosdorf, N. The new global lithological map database GLiM: a representation of rock properties at the Earth surface. Geochem. Geophys. Geosyst 13, Q12004 (2012).

78. Rockman, M., Morgan, M., Ziaja, S., Hambrecht, G. \& Meadow, A. Cultural Resources Climate Change Strategy (Cultural Resources, Partnerships, and Science and Climate Change Response Program, National Park Service, 2016).

79. Vousdoukas, M. I., Velegrakis, A. F., Kontogianni, A. \& Makrykosta, E.-N. Implications of the cementation of beach sediments for the recreational use of the beach. Tour. Manag. 30, 544-552 (2009).

80. Vousdoukas, M. I. et al. Understanding epistemic uncertainty in large-scale coastal flood risk assessment for present and future climates. Nat. Hazards Earth Syst. Sci. 18, 2127-2142 (2018).

81. Hinkel, J. et al. Uncertainty and bias in global to regional scale assessments of current and future coastal flood risk. Earths Future 9, e2020EF001882 (2021).

82. Bove, G., Becker, A., Sweeney, B., Vousdoukas, M. \& Kulp, S. A method for regional estimation of climate change exposure of coastal infrastructure: case of USVI and the influence of digital elevation models on assessments. Sci. Total Environ. 710, 136162 (2020)

83. Kulp, S. A. \& Strauss, B. H. CoastalDEM: a global coastal digital elevation model improved from SRTM using a neural network. Remote Sens. Environ. 206, 231-239 (2018)

84. Yamazaki, D. et al. A high-accuracy map of global terrain elevations. Geophys Res. Lett. 44, 5844-5853 (2017).

85. Anderson, D. G. et al. Sea-level rise and archaeological site destruction: an example from the southeastern United States using DINAA (Digital Index of North American Archaeology). PLoS ONE 12, e0188142 (2017).

86. Eilander, D. et al. The effect of surge on riverine flood hazard and impact in deltas globally. Environ. Res. Lett. 15, 104007 (2020).

87. Okello, C., Tomasello, B., Greggio, N., Wambiji, N. \& Antonellini, M. Impact of population growth and climate change on the freshwater resources of Lamu Island, Kenya. Water 7, 1264-1290 (2015).

88. Cooper, J. A. G. et al. Sandy beaches can survive sea-level rise. Nat. Clim. Change 10, 993-995 (2020).

89. Vousdoukas, M. I. et al. Reply to: Sandy beaches can survive sea-level rise. Nat. Clim. Change 10, 996-997 (2020).

\section{Acknowledgements}

R.R. is partially supported by the AXA Research Fund. N.P.S. received financial support from the UK government's Foreign, Commonwealth \& Development Office and the 
International Development Research Centre, Ottawa, Canada (grant no. 109419 - 001) C.H.T. is supported by the FLAIR Fellowship Programme: a partnership between the African Academy of Sciences and the Royal Society funded by the UK government's Global Challenges Research Fund. N.K. is supported by the Mapping Africa's Endangered Archaeological Sites and Monuments project funded by Arcadia Fund, UK. S.S. is supported by the Leverhulme Trust Doctoral Training Scheme, UK.

\section{Author contributions}

M.I.V., N.P.S., J.C., C.H.T. and R.R. conceptualized the project. M.I.V., N.P.S., S.S., C.E.I., T.M.D and L.R. undertook preliminary and exploratory analysis. M.I.V. and L.F. were responsible for the methodology. M.I.V., N.P.S., J.C., R.R., S.S., C.H.T., L.R., L.M. and L.F did the validation. M.I.V. undertook the formal analysis and investigation, and wrote the original draft. M.I.V., N.P.S., C.H.T. and L.F. were responsible for resources. N.P.S., J.C., R.R., S.S., B.O., N.K., T.M.D. and L.R. were responsible for heritage data curation. M.I.V. N.P.S., J.C., C.E.I., S.S., N.K. and L.R. undertook data integration. M.I.V., N.P.S., J.C.,
R.R., S.S., C.H.T., T.M.D., L.R. and L.F. wrote, reviewed and edited the manuscript. M.I.V, L.R., N.P.S. and N.K. were responsible for visualization; M.I.V., N.P.S. and J.C. for project administration; and C.H.T. for funding acquisition.

\section{Competing interests}

The authors declare no competing interests.

\section{Additional information}

Extended data is available for this paper at https://doi.org/10.1038/s41558-022-01280-1. Correspondence and requests for materials should be addressed to Michalis I. Vousdoukas or Nicholas P. Simpson.

Peer review information Nature Climate Change thanks José Brito, Grégoire Ondoa, Marcy Rockman and Errol Wiles for their contribution to the peer review of this work

Reprints and permissions information is available at www.nature.com/reprints. 


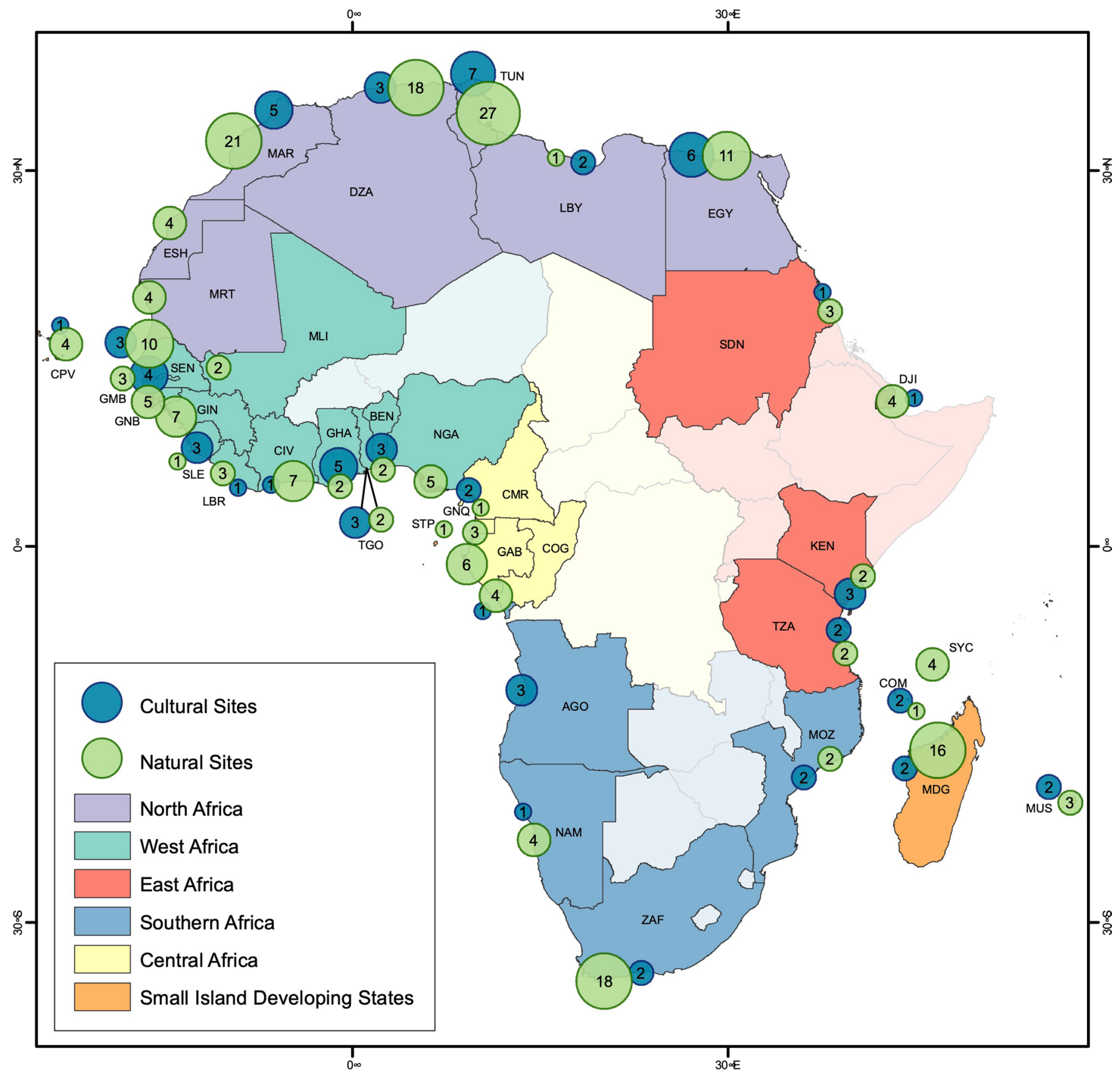

Extended Data Fig. 1 | Coastal AHS per country. Coastal AHS per country. Map of Africa showing the coastal countries and the sub-regions indicated by different colours (North, West, East, Southern, Central Africa and SIDS). For each country the bubbles indicate the total number of cultural (blue) and natural heritage sites (green). 